№ 1 (1), 2021

UDC 659.138

https://doi.org/10.23939/sjs2021.01.030

Mariana Kitsa,

National University "Lviv Polytechnic",

Department of Journalism and mass communication

$\mathrm{PhD}$, associate professor, imkitsa@gmail.com

\title{
METHODS OF USING SOCIAL NETWORKS BY UKRAINIAN JOURNALISTS
}

(C) Kitsa M., 2021

The article identifies the positive and negative aspects of using social networks in the performance of professional duties of journalists. It was found that with the development of social networks, the journalist's life became easier. After all, it has become easier to search for information, more access to sources and people who can comment on certain events. Access to sources and individuals who can comment on certain events has also been greatly facilitated. Access to politicians, public figures and celebrities who can be written on social networks has also been greatly facilitated. In the process of research, the method of systematic study and analysis of individual social networks, such as Facebook, Twitter, Instagram, Foursquare, Tik Tok, was used to write the article. As well as through systematization, analogy and generalization, the materials of in-depth interviews conducted specifically for this study were studied.

Research has shown that journalists can use social networks in different ways in their work. Much depends on the specifics of the job, the tasks and responsibilities of the journalist. That is why the specific cases, situations and experiences of media workers are important, which show how best to use social networks at work depending on the needs and tasks of the journalist, as well as his editorial office and company. This paper outlines the main features and characteristics of social networks, identifies ways to use them by journalists, describes the positive and negative aspects of the use of social networks. It is also analyzed which social networks are suitable for the use of certain tasks in the work of a journalist. Researchers outlined the main opportunities and benefits of using social networks by various organizations and companies, and part of the focus was on the use of this tool by employees of media companies. However, there is no single policy, rules and guidelines for use yet. In general, the tasks set and solved in the research process do not cover the topic of social networks. Further research can be provided on the features and characteristics of social networks, their use by journalists.

Key words: social networks, accounts, journalists, Ukraine.

Introduction. Social networks are becoming more and more popular every year, so journalists cannot ignore these new technologies and actively use them to their advantage.

Some journalists use their accounts to achieve professional goals, for some it is just a platform for expressing personal opinions. In general, the study shows that journalists actively use social networks, both for different and for the same purposes. Next, we will consider in detail the ways of using social networks in the work of a journalist. 
Journalists can use social and networks in different ways. One of the options for application is to find people who are interesting in the highlighting specific topics. One more opportunity for journalists is using social networking can find people who will be speakers for their materials or they can hold a special interview. Social networks can help identify people who are interesting and use them as a source for material. Searching for such individuals, the journalist can look into the group on Facebook or use a special hashtag on Twitter to find one subject networks.

Purpose of the article is to examine opportunities for using social media by journalists.

Discussion. Ukrainian researcher T. Fisenko notes that social networks are gradually beginning to cover almost all areas of interest. «First of all, if the information request and information need are relevant and popular, on this basis a new social community is immediately created» [4].

L. Gorodenko notes that at the beginning of the new millennium the establishment of understanding of media and communication has changed. In particular, she talks about increasing information flows and developing communication channels. "Social media as one of the most active and the most popular forms of network communication for the last time is increasing more and more features of social communication [2].

Researcher Lazareva believes that the most important component of modern development of communication Internet networks is the ability to instantly exchange all types of digital information. «At the same time, thanks to the development of Internet networks, such a service can be used from anywhere in the world, including mobile devices. However, despite these advantages, communication Internet networks now generate a lot of problems in terms of information security implementation threats to the integrity and availability - a lot of current users use services communications Internet-networks for the exchange of valuable information (correspondence which can be passwords, important information and schemes). Networks realize the threat of confidentiality - possible falsification, huge amount of spam information, unauthorized distribution of intellectual property, etc.» [8].

Phenomenon of appearance and operation of communication networks using the Internet features are an integral part of modern information and socio-cultural space, that it puts the need for further study of this phenomenon as a phenomenon expert in various industries.

«Billion of people create trillions of connections through social media every day, but few of us are thinking as a click and keystrokes builds relationships, which together form a huge social network»,-noted in his study of Derek Han Sen, Ben Schneider and Mark A. Smith [1]. They write that passionate users of social media, such as e-mail, blogs, microblogs, wikis, are eager to send personal or public messages, post emotionally colored thoughts. Selected social networks create and distribute digital media, and evaluate or recommend resources for information unity of his experience assisting neighbors and colleagues, and express their creativity. «The results are huge, complex networks called connection that connect people with each other, documents, concepts and others objects» [9].

Derek Hansen, Ben Schneider and Mark A. Smith noted the fact that social media have become widespread as a platform for invisible human interactions, shackles that are called friendship with each other, have become more prominent and measurable for machines [7]. According to researcher Peter K. Ryan, the ability to communicate around the planet in real time has contributed to the development of completely new forms of social networks that have never existed before [13].

L. Gorodenko notes that in the conditions of rapid development of the Internet and other newest channels of information transmission, network communications are becoming more and more popular and rated. «In a short time, they have become a powerful factor that, along with ineffective means, affects all areas of socio-economic, socio-political, scientific, cultural life of modern society. In essence, network communication is another form of development of one of the communication channels, which is implemented in cyberspace» [2]. 
For better understanding how social networks are used by modern journalists, let's look at their experience. In particular, Anna Medvedeva notes that social media is a very useful thing for finding sources. «If I'm looking for people to interview, social media can identify the places to find me characters that could be witnessed events and can be good orators of his words» [3].

According to Diana Kuryshko, social networks help to find not only people for interviews, but also whole stories. «We see more and more often that social networks, which should only be the way we use to promote ourselves, are now the way stories are told. And if we do not pay attention to social media, we just miss history» [10].

The journalist believes that with the help of social networks you can learn many interesting stories. After all, actors, singers, musicians, politicians, such people are involved in social media, and this can be a key source for stories.

«Any journalist who thinks that social media is just a place where someone says something about what kind of pizza they had for dinner, or shares photos of their cat, omitting the fact that these platforms allow global conversations to take place» [12].

She also points out that if before you had to read a German newspaper or watch Japanese television to find out what was happening in Germany and Japan, now you can do it with one click. According to her, this makes the world a much smaller place.

Natalia Humeniuk notes that she uses social networks in her work all the time. «Part of my job is to use social media,» she said. She uses Facebook the most. At the same time, the journalist noted that in general $98 \%$ use this network for work.

«It works for me as an information filter, my own news agency», she explained. Natalia uses this social network to read news from various foreign publications, Ukrainian journalists, in fact uses Facebook as a news feed. «If I open Facebook, I don't have to open many different sites, I read Ukrainian news only from Facebook, because I know that they are better filtered there», the journalist emphasizes [5] .

Instead, the editor of the online publication «Tochka. net «Diana Kuryshko says that she uses social networks in her work constantly. «In social networks, we draw inspiration and follow the pages of famous people. For example, for Victoria Beckham, Madonna, Piano, Ksenia Sobchak», says Diana. For the portal «Tochka. net» social networks have always been one of the main sources of information for writing materials. «Sometimes news appears faster on Twitter and Facebook than on news feeds», says the editorin-chief.

Social media assisted Natalia Humeniuk as she covered the US presidential election. I myself was in New York myself as a freelancer and had a bunch of friends on Facebook, journalists I knew. I learned a lot more from the people of New York, who are on Facebook about what's going on there than from the media.

Journalists can use social media to watch what people are saying, what stories they are telling, telling and reading. «Listening to what people are saying can give you an opportunity to think about a corner in history you never thought about before», Barnes told us.

Another area of application of social networks is the search for interesting topics. Some people directly monitor social media in order to understand the pulse of the blogosphere, the pulse of public discussion. Thus we can define some current issues, which then editors can continue to develop. Journalists emphasize that many publications make exclusive materials through social networks. One application is to find an exclusive based on the social media activity of some famous people, or officials or their children. Moreover, profiles on social networks allow you to form a portrait of some people through their personal information.

«Social networks help my work a lot. I believe that this is one of the most important means of finding information for journalists. With their help, I find at least 50\% of topics and stories for news, through them I find heroes for publications, photos of heroes of publications. If there is an accident (accident, suicide, murder, etc.), then knowing the names of the participants in the accident in $90 \%$ of 
cases, I still find these participants or their friends (colleagues, relatives) on social networks. In $80 \%$ of cases, they agree to give a comment or interview for publication», said journalist Oleksiy Ladyka [6].

Natalia Humeniuk says that Facebook has repeatedly helped her to find information and comments in covering various stories from abroad. When she published information that she was going to a certain country, her fellow journalists gave her contacts of people who could meet her in that country and help.

«I was helped by social media in finding heroes or commentators for my materials. For example, I wrote about Ukrainians who lived and studied abroad, then returned to Ukraine. Do they want to stay there or return to Ukraine? And that's where I opened my friend tape, looked at it as a personal database. I know that this and that studied abroad, someone has a foreign educational institution in his biography. And so I optimized my time. I didn't run down the street, I didn't look for people, I didn't ask acquaintances, I didn't ask someone who studied abroad. For such life topics, social media is a unique tool that allows you to find people» [4].

Results. Social networking has become an important component of the communication system. Over the past few years, they have made significant changes in the work of media practitioners. Using social networks can facilitate and speed up the work of the journalist, but it should be handled with care.

The social network Twitter, when used properly, can also bring a lot of information about recent events. In particular, the journalist can subscribe to accounts of various international news agencies, media, and prominent journalists from around the world. In this way, journalist will have an opportunity to see what they are writing about and will be up to date with the latest news from around the world. Instagram journalists can use to claim research for interesting images related to the life of famous people. Foursquare is not much used by Ukrainian journalists at present. However, some media practitioners use this social network to monitor when and where celebrities are. Instead, the relatively new social network Tik Tok is still rarely used by Ukrainian journalists, mostly to track the activity of celebrities and so on.

It is worth noting that each social network has its own specifics. Knowledge of the characteristics of individual social networks helps journalists to use them most effectively. After various social networks can help in different ways to solve specific tasks, depending of thier functionality.

We turned out that most journalists use social networks to find information. It is determined that journalists use social networks to follow what different people write and what topics they discuss. In addition, having friends or subscribing to the accounts of politicians, public figures, celebrities, a journalist can easily and quickly learn the latest news.

Journalists also use social media to search for stories and characters for their material. With the help of these tools you can find the right person, no matter what part of the world he is in, take a comment on a particular situation.

With the help of social networks, journalists expand their audience, promote materials, attract the attention of readers. Use them as OJ for reverse -called 'communication feedback from readers. The ability to comment on publications allows journalists to quickly obtain information about the audience's opinions about their materials.

Conclusions. In the article is identified positive and negative aspects of the use of social networks during the performance of professional required ' bonds. It was found that with the development of social networks, the journalist's life became easier. After all, it has become easier to search for information, more access to sources and people who can comment on certain events [14]. Access to sources and individuals who can comment on certain events has also been greatly facilitated. Access to politicians, public figures and celebrities who can be written on social networks has also been greatly facilitated. 
However, a large amount of unverified information on social networks can harm journalists if they are not careful. After all, posts on social networks can contain false information, so before you publish it in your own media, you need to carefully check. Another negative aspect in the use of social networks is that the journalist is too open. In particular, readers can easily find a journalist's profile, read where he is, what he does outside of work, can track his activities, and can negatively comment his materials.

Thus, the use of social networks has both positive and negative consequences. To reduce the negative aspect of the use of social networks, you need to take a professional approach to this issue. The editorial offices are introducing social codes of ethics for the use of social networks. If abroad such codes are already established, in the Ukrainian media so far everything is based on unwritten rules and verbal agreements.

Social networking on the Internet is actively developing, constantly expanding capabilities provide many different tools to use. At the same time, the number of users is constantly growing. Journalists are increasingly using social networks in their work. This gives grounds to claim that this area is promising for further research.

This paper outlines the main features and characteristics of social networks, identifies ways to use them by journalists, describes the positive and negative aspects of the use of social networks. It is also analyzed which social networks are suitable for the use of certain tasks in the work of a journalist.

However, the tasks set and solved in the research process do not cover the topic of social networks. It is worth to provide further research on the features and characteristics of social networks, their appropriate use by journalists.

\section{REFERENCES}

1. Cinelli M., Quattrociocchi W., Galeazzi A., Valensise C. M., Brugnoli E., Schmidt A. L., ... \& Scala A. (2020). The covid-19 social media infodemic. arXiv preprint arXiv:2003.05004.

2. Gorodenko L. M. Terminological discourse of network communication resources//Scientific notes of the Institute of Journalism. T. 41. 2010. P. 53-57.

3. Instagram [Online]: [Social networking]. Stanford, 2014-2020. - Available from http://instagram.com.

4. Fiksenko TV Social Internet networks as a means of meeting information needs// Scientific notes of the Institute of Journalism. T. 41. 2010. P. 190-194.

5. Jose Luis Orihuela : Profile [Online]. Facebook [Website]. 2020.

Available from: http://www. facebook.com / jlorihuela.

6. Jose Luis Orihuela: Profile [Online]. Twitter [Website]. 2020.

Available from : http:// twitter.com/ jlori.

7. Journalists and social media [Online]. Center for Media Research. Nepal. 2015. Avalible from: http:// research.butmedia.org/wpcontent/ uploads/2015/06/Journalist_Social_Media_CMR_Nepal.pdf (17.10.2015).

8. Lazareva L. M. Communication Internet networks as a phenomenon of modern information space// Scientific notes of Rivne State University for the Humanities. Vol. 2. 2010.

9. Memon N. Data Mining for Social Network Data// edit. Nasrullah Memon, Jennifer Jie Xu, David L.Hicks, Hsinchun Chen. Information Systems. N.Y.: Springer, 2010-2015.

10. Mykola Malukha: Profile [Online]. Facebook [Website]. 2016.

Available from : http://www. facebook.com / mykola.malukha.

11. Myroslava Petsa: Profile [Online]. Facebook [Website]. 2020.

Available from : http:// facebook.com/ myroslava.petsa.

12. Mykola Malukha: Profile [Online]. Twitter [Website]. 2020.

Available from: http:// twitter.com/ jesfor.

13. Poynter R. The Handbook of Online and Social Media Research: Tools and Techniques for Market Researchers. Ray Poynter. 2010.

14. Zhytaryuk M. G. Sociocultural model of journalism: traditions and innovation. Lviv, 2008. 416 p. 
Мар'яна Кіца

\section{МЕТОДИ ВИКОРИСТАННЯ СОЩАЛЬНИХ МЕРЕЖ УКРАЇНСЬКИМИ ЖУРНАЛІСТАМИ}

У статті визначено позитивні та негативні аспекти у використанні соціальних мереж під час виконання професійних обов'язків журналістів. Було встановлено, що з розвитком соціальних мереж життя журналіста полегшилось. Адже стало простіше шукати інформацію, відкрився більший доступ до джерел та осіб, які можуть прокоментувати певні події. Також значно полегшився доступ до джерел та осіб, які можуть прокоментувати певні події. Також значно полегшився доступ до політиків, громадських діячів та відомих особистостей, якими можна написати в соціальних мережах.

У процесі дослідження для написання статті було застосовано метод системного вивчення й аналізу окремих соціальних мереж, таких як: Facebook, Twitter, Instagram, Foursquare, Tik Tok. A також за допомогою систематизації, аналогії та узагальнення було досліджено матеріали глибинних інтерв'ю, проведених спеціально для цього дослідження.

Дослідження показали, що журналісти можуть по-різному використовувати соціальні мережі у своїй роботі. Багато що залежить від специфіки роботи, поставлених завдань та обов'язків журналіста. Саме тому важливим є конкретні випадки, ситуації та досвід працівників ЗМІ, які показують, як краще використовувати соціальні мережі в роботі в залежності від потреб та завдань журналіста, а також його редакції та компанії. У даній роботі окреслено основні особливості та характеристики соціальних мереж, встановлено способи їнього використання журналістами, описано позитивні та негативні аспекти у використанні соціальних мереж. Проаналізовано також, які соціальні мережі підходять для використання певних завдань у роботі журналіста.

Науковці окреслили основні можливості та переваги використання соціальних мереж різними організаціями та компаніями, також частина уваги була зосереджена на використанні цього інструменту працівниками медіа компаній. Проте сдиної політики, правил та настанов щодо використання поки що немас.

Проте поставлені та вирішені в процесі дослідження завдання не вичерпують тему соціальних мереж. Доцільними є подальші дослідження щодо особливостей та характеристик соціальних мереж, їхнього використання журналістами.

Ключові слова: соціальні мережі, акаунти, журналісти, Україна. 